\title{
The beginning of human life
}

\section{Status of embryo. Perspectives in Halakha (Jewish Religious Law)}

\author{
Joseph G. Schenker
}

Received: 13 March 2008 /Accepted: 16 April 2008 / Published online: 13 June 2008

(C) Springer Science + Business Media, LLC 2008

\begin{abstract}
Introduction The Jewish religion is characterized by a strict association between faith and practical precept. Jewish law has two sections, the written and the oral tradition. The foundation of the written law and the origin of authority is the Torah, the first five books of the Scripture. It is an expression of God's revelation, teaching and guiding humanity. The oral laws interpret, expand, and elucidate the written Torah and behavior patterns regulate new rules and customs. The main parts of the oral law are as follows: the Mishnah, the Talmud, Post-Talmudic Codes and. Responsa Literature.

Discussion Life is a process that has a beginning and an end. The consensus about the time when human life really begins is still not reached among scientists, philosophers, ethicists, sociologists and theologizes. The scientific data suggested that a single developmental moment marking the beginning of human life does not exist. Current biological perspectives on when human life begins range through fertilization, gastrulation, to birth and even after. The development of a newborn is a smoothly continuous process.

Results Procreation is acknowledged in the Bible to be the gift of God. The (Halachic) Jewish interpretation of when human life begins is extracted predominantly from procreation is acknowledged in the Bible to be the gift of God. The Jewish interpretation of when human life begins is
\end{abstract}

Capsule Presented at the International Symposium on "Beginning of Human Life," Zagreb, September 2007.

J. G. Schenker $(\square)$

Department of Obstetrics and Gynecology, Hebrew University,

Hadassah Medical Centre,

Jerusalem, Israel

e-mail: schenker@cc.huji.ac.il extracted predominantly from The Halachic sources. The Bible does not make any other direct references regarding the beginning of human life.

Conclusion While the Talmud gives the full status of humanness to a child at birth, the rabbinical writings have partially extended the acquisition of humanness to the 13th postnatal day of life for full-term infants. The Babylonian Talmud Yevamot 69b states that: "the embryo is considered to be mere water until the fortieth day." Afterwards, it is considered subhuman until it is born. The issues of abortion, embryo research, multifetal reduction and cloning will be discussed according to Jewish Law perspectives. Life is a process that has a beginning and an end. The consensus about the time when human life really begins is still not reached among scientists, philosophers, ethicists, sociologists and theologizes. The scientific data suggested that a single developmental moment marking the beginning of human life does not exist. Current biological perspectives on when human life begins range through fertilization, gastrulation, to birth and even after. The development of a newborn is a smoothly continuous process.

Keywords Embryo $\cdot$ Human life $\cdot$ Cloning $\cdot$ Preembryo Jewish religion

\section{Jewish Religious Law (Halakha)}

The Jewish religion is characterized by a strict association between faith and practical precept. Jewish law has two sections, the written and the oral tradition [1].

The foundation of the written law and the origin of authority is the Torah, the first five books of the Scripture. It is an expression of God's revelation, teaching and guiding humanity. 
The Torah is viewed as a single unit a divine text that obligates moral values as well as practical laws. The oral laws interpret, expand, and elucidate the written Torah and behavior patterns regulate new rules and customs. The authority is derived from the written Torah. The main parts of the oral law are as follows:

1. The Mishnah. This early textbook was compiled systematically by numerous scholars over a few centuries. Its final form was established early in the third century. The Mishnah includes early traditional and original interpretations of the written Torah, ancient regulations that are not written in the Torah, and postBiblical regulations.

2. The Talmud. For approximately three centuries after the final compilation of the Mishnah, the great interpreters studied the six orders of the Mishnah contributed to a monumental composition know as the Talmud. The great interpreters (Amoraim) included in the Talmud commentaries and interpretative studies of the Mishnah and Midrashim and established regulations and new customs.

3. Post-Talmudic codes. An enormous amount of Talmudic knowledge was essential for accurate ruling.

These post-Talmudic codes were compiled with the intention of assisting access to the laws, regulations, and customs of the Talmudic Halakha. Different scholars until the 16 th century summarized and reviewed the Halakhic conclusions of the Talmud in the post-Talmudic codes. Among the scholars were Rashi (1040-1105), Rabbi Moshe Ben Nachman (1195-1270), and Rabbi Menachem Ben Shlomo Hameiri (1249-1316). The most prominent postTalmudic codes are Sheilot, Halakhot, Maimonides, Piskey Harosh, Shulhan Arukh.

4. Responsa. The various attitudes of rabbinic scholars about the way Halakha should be applied in a changing world is analyzed and discussed with regard to the legal codes, and written opinion has been given by qualified authorities throughout ages to questions about aspects of Jewish law.

Responsa is a term usually confined to written replies given to questions on all aspects of Jewish law by qualified authorities from the time of the later Geonim to the present day. About 1,000 volumes, containing more than half a million separate Responsa, have appeared in print. Contemporary rabbinic scholars deal with new problems that arise in the wake of scientific advancement. Moreover, the Responsa of later rabbinic authorities are often short monographs in which every text remotely relevant to the point at issue is quoted or discussed.

Procreation is acknowledged in the Bible to be the gift of God. The (Halachic) Jewish interpretation of when human life begins is extracted predominantly from following sources: the Torah, the Talmud, and the Responsa (rabbinical writings). A basic biblical identification of life with breath is pointed in Torah and other books of Tanach (Bible).

\section{Torah}

The first detailed description of the creation of a human being by God points to the moment when human life begins. "Yahveh God formed the man from the dust of the earth and breathed into his nostrils the breath of life and the man became a living nefesh" (the first breath). Life began for human being when God breathed breath into him (Genesis 2.7).

Additional Statements in the Torah demonstrate that breath is understood to be essential to life; and that when the breathing stops, life ends. "And all flesh that moved on the earth perished, birds, cattle, wild animals all swarming creatures that swarm upon the earth and all human beings. Everything which had the nishmat (breath) of life in its nostrils, all that were on dry land died" (Genesis 7.21-22).

The Bible does not make any other direct references regarding the beginning of human life. The conclusion as to when human life begins can be obtained from the Torah's stated position on the issue of abortion.

And if men strive together, and hurt a woman with a child, so that her fruit depart (if she miscarries) and yet no harm follow, he shall be surely fined, according as the woman's husband shall lay upon him; and he shall pay as the judges determine. But if any harm follow, then shalt thou give life for life... (Exodus 21: 22-23)

According to the Jewish interpretation," if no harm follow the hurt to the woman resulting in the loss of her fruit refers to the survival of the woman following her miscarriage; in that case there is no capital guilt involved, and the attacker is merely liable to pay compensation for the loss of her unborn child. "But if any harm follow," i.e., the woman is fatally injured, then the man responsible for her death has to give "life for life". In that event the capital charge of murder exempts him from any monetary liability for the aborted fruit [2]. From the interpretation of this passage it can be inferred that the killing of an unborn child is not considered murder punishable by death in Jewish law. What is explicitly stated in the Jewish law is that murder is an offense that is punishable by death: "He that smiteth a man, so that he dieth, shall surely be put to death" (Exodus 21:12).

The Responsa literature reached from these two passages the conclusion that the capital charge of murder should be used for death of "a man, but not a fetus". It means that 
complete human life does not begin at the embryonic or fetal stage of development.

The Septuagint - the translation of the Hebrew Bible into Greek by 72 Jewish Scholars, 270 BC-renders the word ason not as 'casualty' or 'serious injury' but as 'form.' This gives a completely different meaning to the passage. The first verse, in which there is a liability, compensation, refers to the miscarriage of an 'unformed' fetus. The second, which speaks of a capital crime, refers to a 'formed' fetus, in other words one sufficiently developed to have a recognizably human shape. [This, is the source of the teaching of the Church, from Tertullian who was ignorant of Hebrew onwards through later church fathers, that at a certain stage the fetus is a person and that abortion is a form of homicide.

This position was further reinforced by the belief that the "animation" (entry of the soul) of a fetus occurred on the fortieth or eightieth day after conception for males and females respectively, an idea first expressed by Aristotle and by the doctrine, firmly enunciated by Saint Augustine and other early Christian authorities, that the unborn child was included among those condemned to eternal perdition if he died un-baptized. Some even regarded the death or murder of an unborn child as a greater calamity than that of a baptized person.

Eventually the distinction between animate and inanimate fetuses was lost; and since 1588, the Catholic Church has considered as murder the killing of any human fetus from the moment of conception.

This position is maintained to the present day. It assumes that potential life, even in the earliest stages of gestation, enjoys the same value as any existing adult life. Hence, the Catholic Church never tolerates any direct abortion, even when, by allowing the pregnancy to continue, both mother and child will perish; following the principle two deaths are better than one murder].

\section{Talmud}

The Jewish Talmudic Law assumes that the full title to life arises only at birth. Accordingly, the Talmud rules (Talmud, Tohoroth II Oholoth 7:6). A passage from the Mishna describes the situation in which a woman's life is endangered during childbirth.

If a woman is in hard labor sand her life cannot otherwise be saved\}, one cuts up the child within her womb and extracts it member by member, because her life comes before that of the child. But if the greater part \{or the head\} was delivered, one may not touch it, for one may not set aside one person's life for the sake of another.
The legal text states that the fetus must be dismembered and removed limb by limb. However, if "the greater part" of the fetus had already been delivered, then the fetus should not be killed. This is based on the belief that the fetus only becomes a person when most of its body emerges from the birth canal. Before personhood has been reached, it may be necessary to "sacrifice a potential life in order to save a fully existent human life, i.e. the pregnant woman in labor." After the forehead has emerged from the birth canal, the fetus is regarded as a person. Neither the baby nor the mother can be killed to save the life of the other.

A second consideration is the principle of self-defense. Some Jewish authorities have asserted that if the fetus placed its mother's life at risk, then the mother should be permitted to kill the fetus to save herself, even if the "greater portion [of its body] had already emerged" from the birth canal.

This ruling, sanctioning embryotomy to save the mother in her mortal conflict with her unborn child, is also the sole reference to abortion in the principal codes of Jewish law. They add only the further argument that such a child, being in "pursuit" of the mother's life, may be destroyed as an "aggressor" following the general principle of self-defense.

This formulation of the attitude toward abortion in the classic sources of Jewish law implies:

1. That the only indication considered for abortion is a hazard to the mother's life.

2. That, otherwise, the destruction of an unborn child is a grave offence, although not murder.

3. That it can be viewed that the fetus is granted some recognition of human life, but it does not equal that of the mother's, and can be sacrificed if her life is in danger.

While the Talmud gives the full status of humanness to a child at birth, the rabbinical writings have partially extended the acquisition of humanness to the thirteenth postnatal day of life for full-term infants. This designation is based on the viability of the infant, so the acquisition of humanness occurs later for premature infants, because the viability of premature infants is still questionable after thirteen days.

Rashi, the great twelfth century commentator on the Bible and Talmud, states clearly of the fetus 'lav nefesh hu-It is not a person.'

Objection to abortion in Jewish Law is thus strong but not absolute. It is not permitted even if the fetus carries a genetic conditions or other congenital malformation; nor for social reasons. Abortions are not permitted for economic reasons, to avoid career inconveniences, or because the woman is unmarried. However, some Rabbinical authorities have been known to approve abortion in the early stages of gestation, within the first forty days, during which it is, 
according to one talmudic statement, 'mere water'. The Babylonian Talmud Yevamot 69b states that: "the embryo is considered to be mere water until the fortieth day." Afterwards, it is considered subhuman until it is born.

The fetus has great value because it is potentially a human life. It gains "full human status at birth only."

Each case of abortion must be decided individually by a rabbi well-versed in Jewish law.

Israel State legislation [3], the Criminal Law Amendment (Interruption of Pregnancy) of 31 January 1977 increased the circumstances under which abortions could be legally performed. It permitted abortions if the continuation of the pregnancy was likely to endanger the woman's life or cause her physical or mental harm, if the woman was under the age of marriage or over 40 years of age, if the pregnancy resulted from a sexual offence, incest or extramarital sexual intercourse, or if the child was likely to have a physical impairment. The penalty imposed on a person performing an illegal induced abortion is imprisonment to up to 5 years.

Performance of an abortion required the approval of a three-member committee consisting of a social worker and two medical practitioners, one of whom was an obstetrician/gynaecologist. The committee was required to give its approval in writing and to set out the grounds justifying the abortion. The pregnant woman was required to give her written consent, after the physical and mental risks and consequences involved in the procedure had been explained to her. The consent of a minor did not require the approval of her representative. An abortion had to be performed by a physician in a recognized medical institution. According to Israel State legislation, the Criminal Law feticide can be carried out at any stage of pregnancy until birth as is mention in Mishna based on the belief that the fetus only becomes a person after most of its body emerges from the birth canal.

\section{Multiple pregnancy reduction}

In recent years, there has been a dramatic increase in multiple pregnancies throughout the world. Undoubtedly, the main factor has been the use of ovulation inducing drugs and of multiple embryo transfer in the treatment of infertility. Multiple pregnancy has very serious implications for the mother and for her offspring, for the family, community, and for health service resources. Multifetal pregnancy reduction was initially used selectively to terminate a fetus affected by a genetic disorder.

This procedure of multifetal pregnancy reduction (MFPR) is now considered an efficient and safe way to improve the outcome. According to Jewish law the fetus is regarded as a part of the mother's body and not as a separate being until it begins to egress from the womb during parturition, and attains the status of 'nefesh,' which means soul in Hebrew.

Abortion on demand is repulsive to the ethics of the Halakha; however as we have seen, in some situations a pregnancy may be terminated. If, for 'example, the mother's life is in danger, as in sometime the case is in multiple pregnancy a fetus is a Rodef; an aggressor who may even or must be killed in order to save the individual in danger. Most rabbis permit and even mandate abortion when the health or life of the mother is threatened. Some authorities are stringent and require the mother's life to be in actual danger, however remote that danger, whereas others permit abortion for a serious threat to the mother's health.

The question of multifetal pregnancy reduction was debated in the Responsa literature by rabbinical authorities. If the mother's life is in danger, each fetus is a rodef and can be killed to save the mother. But if the danger is to the fetuses and not to the mother, each fetus is an aggressor and victim with equal status. In this case, it might not be permissible to put aside one soul for the sake of another. Searching for a legal analogy for this situation, some Rabbis focused on the case of a group of people who are in mortal danger and who can be saved by sacrificing one innocent member of the group. Most Halakhic authorities agree that in such a case all must allow themselves to die rather than sacrifice an innocent person. If, however, it is absolutely certain that all would be lost unless one is forfeited, these same authorities would allow some innocent people to be selected randomly and sacrificed to save the others. This conclusion is applicable to cases of a viable person. In the case of fetuses who are already condemned to death, multifetal reductions might well be allowed. The number of fetuses to be destroyed is a medical question that should be decided by the doctors involved, who must determine the minimum number that need to be reduced to ensure a good prognosis for the mother and remaining fetus.

\section{Human embryo and assisted reproduction}

The development of assisted reproductive technologies has made it necessary to consider the question of the beginning of life and the moral status of the embryo from different perspectives.

Many forms of infertility treatment consist precisely of producing embryos outside the woman's body by in vitro fertilization with a view to subsequently implanting them in the uterus, where they have the opportunity to develop into full-term children. The fact that this is even feasible shows 
that the embryos have not taken on a different character by being created outside the woman's body.

The basic fact that allows IVF-ET to be considered in the rabbinical literature at all is that the oocyte and the sperm originate from the wife and husband based on the commandment of procreation stated in the Bible (Old Testament, Genesis 1:18). The Jewish majority's religious point of view, however, as formulated by the chief rabbis of Israel, supports both IVF and ET [4, 5].

\section{Embryo research}

Various criteria exist in Jewish law which determine the status of a fetus or an embryo. One fundamental principle that is agreed upon by all branches of the Jewish faith and that is that full human status is not acquired until birth. Thus, until then, the destruction of a product of conception does not constitute homicide culpable as murder. Although the Jewish law refuses to grant a full human inviolability to the unborn child from conception, it is clearly agreed that the potentiality for life must not be compromised except for the most substantial medical reasons. Man's creation "in the image of G-d" confers infinite value on every human life and renders its destruction a capital offence. Since the preimplantation pre- embryo carries a low probability of reaching the neonate stage, and achieving full human status, it does not enjoy the same sacred title to life as the fetus or embryo, and its status is similar to that of human semen. Nevertheless the destruction of human seed or embryo is considered a grave violation of the law.

According to the Talmud, during the first 41 days from fertilization until the completion of organogenesis, the embryo is defined as "plain water", for the purpose of certain laws. Pre-embryo research may be therefore permissible if it is carried out in order to enable the sperm owner to have his own child. It is prohibited to use a preimplantation pre-embryo for research, unless specific medical research. The destruction or use of a pre-implantation pre-embryo for research is forbidden, as long as it has the potential to implant. It is permitted to create In vitro pre-implantation pre-embryos for research if there are real chances that the sperm owner may benefit and have a child as a result of this research. When this does not apply, then the creation of a pre-embryo for research purposes is strictly forbidden.

\section{Cryo-preservation}

Cryopreservation of pre-embryos is routinely practiced in IVF programmes. Because cryo-preservation stops the development and growth of the embryo, it raises the basic question of whether it cancels all rights of the pre-embryo's father. As far as the mother is concerned, the difficulty is removed, since the pre-embryo is transferred into her uterus. As for the father, whose main function is to fertilize the oocyte to form the pre-embryo, the period of freezing may sever his relationship with the child. Freezing the spermatozoa and pre-embryo is permitted in Judaism only when all measures are taken to ensure that the father's identity will not be lost.

\section{Cloning}

Animal models have demonstrated that in several mammalian species, such as mice, sheep and cows, SCNT has resulted in live births that developed into healthy adult animals. This would suggest that reproductive cloning could be achieved in humans.

Perspectives for applying cloning technology to human reproduction have generated much controversy. Worldwide legislations has banned reproductive cloning.

The Jewish religion takes the position that reproductive human cloning could conceivably be justified in some circumstances. This view is largely based on historical tradition and sacred writings, which largely focus on human destiny. The Jewish tradition emphasizes that man is in partnership with God. Some Jewish thinkers find justification for this view in the story of Genesis, which says that Adam and Eve were 'to work it [the garden] and to preserve it' (Old Testament, Genesis 2). Jewish scholars do not believe that potential violations of human dignity are reason enough to prohibit human cloning. They believe that the potential benefits of developing cloning technology outweigh the potential risks, provided man fulfils his obligation to minimize violations of human dignity. Some Jewish thinkers fear that cloning human beings might harm the family by changing the roles and relationships between family members that define their responsibilities to one another and patterns of inheritance. In Judaism religious status is passed down through the mother and tribal designation is passed down through the father. Thus, a child needs both a mother and a father. However, many regard cloning of a family member as more acceptable than donor insemination or egg donation.

Jewish Law is squarely situated on the side of medical research that has potential to save and preserve life. Given this presumptive duty, it is possible to support therapeutic cloning as a remedy for diseases. Since Jewish law does not grant full moral status to the human embryo, therapeutic cloning research conducted on the early human embryo may be acceptable. 
Definitions of a human embryo normally include those entities created by the fertilization of a human oocyte by a human sperm. However, there have been a number of recent technological developments that have made it possible to create entities called embryos by other means, such as somatic cell nuclear transfer (SCNT) and induced parthenogenesis [6]. Applying such new technology will likely be prohibited by Rabbinical Authorities.

The development in future of such new "entities", embryos which might result in live births when transfer to women uterus will even more confuse the issue when human life begins.

\section{References}

1. Schenker JG, Halperin M. Jewish family practice and their evolution. Glob Bioeth 1995;1:35.

2. Jakobovitz I. Jewish view on abortions. In: Rosner F, Bleich JD, editors. Jewish bioethics. New York: Sancherin; 1979. p. 118.

3. Law. Termination of pregnancy. State Israel, 1977.

4. Schenker JG. Women's reproductive health: monotheistic religious perspectives. Int J Gynaecol Obstet 2000;70:77.

5. Schenker JG. Assisted reproductive technology in Israel. J Obstet Gynaecol Res 2007;33 Suppl 1:51.

6. Findlay K, Gear ML, Illingworth PJ, Junk SM, Kay G, Mackerras $\mathrm{AH}$, et al. Human embryo: a biological definition. Hum Reprod 2007;22:905 